\title{
A SURVEY ON POLISH CONSUMERS' PERCEPTIONS OF MEAT PRODUCED FROM STEM CELLS IN VITRO
}

\section{POSTRZEGANIE MIĘSA WYTWORZONEGO Z KOMÓREK MACIERZYSTYCH IN VITRO PRZEZ POLSKICH KONSUMENTÓW W ŚWIETLE BADAŃ ANKIETOWYCH}

\author{
Stanislaw Popek \\ Cracow University of Economics \\ ul. Rakowicka 27, 31-510 Kraków, Poland \\ popeks@uek.krakow.pl ORCID 0000-0002-3681-1679 \\ Bogdan Pachołek \\ Poznan University of Economics and Business \\ al. Niepodległości 10, Poznan 61-875, Poland \\ bogdan.pacholek@ue.poznan.pl ORCID 0000-0003-0576-1426 \\ DO|: 10.2478/minib-2021-0021
}

\section{ABSTRACT}

Despite the dynamic development of technology related to the production of artificial meat, this product faces one more important challenge in terms of gaining consumer acceptance. In the literature on the subject, limited research has been done on the perception of meat in vitro across different societies; therefore, there is little knowledge of the possibility of its acceptance and the type of barriers it may encounter. The aim of this study was to assess the perception of meat produced from stem cells in vitro by Polish consumers. The study was voluntary and was conducted based on an internet survey addressed to people aged 12 to $60+$. Convenience sampling of respondents was used. The research sample consisted of 424 respondents with a diversified sociodemographic profile. The results showed a diversified interest in meat produced from stem cells in vitro among Polish consumers. Many respondents were not able to clearly define their preferences for this type of product. Young people showed the greatest positive interest in innovative in vitro meat. The greatest concerns of consumers were related to the lack of knowledge about this type of food, the lack of its inherent naturalness and potential negative health effects. 


\section{ABSTRAKT}

Pomimo dynamicznego rozwoju technologii związanej z produkcją sztucznego mięsa, przed tym produktem stoi jeszcze jedno ważne wyzwanie, jakim jest akceptacja konsumentów. W literaturze przedmiotu istnieją ograniczone badania dotyczące postrzegania mięsa in vitro przez różne społeczeństwa, dlatego wiedza na temat możliwości jej akceptacji i rodzaju barier jest niewielka. Celem niniejszych badań była ocena percepcji mięsa wyprodukowanego z komórek macierzystych in vitro przez polskich konsumentów. W badaniu wykorzystano ankietę jako metodę badawczą. Badanie miało charakter dobrowolny i zostało przeprowadzone na podstawie ankiety internetowej skierowanej do osób w wieku od 12 do 60+. Zastosowano procedurę ochotniczego doboru respondentów. Próba badawcza liczyła 424 respondentów o zróżnicowanym profilu społeczno-demograficznym. Wyniki badań wykazały zróżnicowane zainteresowanie wśród polskich konsumentów mięsem produkowanym z komórek macierzystych in vitro. Respondenci nie byli w stanie jednoznacznie określić swoich preferencji dla tego typu produktu. Młodzież najbardziej pozytywnie zainteresowała się innowacyjnym mięsem in vitro. Największe obawy konsumentów dotyczyły braku wiedzy na temat tego rodzaju żywności, braku wrodzonej jej naturalności oraz potencjalnych negatywnych skutków zdrowotnych.

Słowa kluczowe: percepcja konsumentów, akceptacja konsumentów, mięso in vitro, sztuczne mięso, innowacyjny produkt spożywczy

JEL: D12, D91, D19, 039

\section{Introduction}

The growth of the world population and the increasing income of societies in recent years have contributed to the improvement of the standard of living and thus to the increase of the world consumption of meat (de Boer, Schösler \& Aiking, 2014). The UN Food and Agriculture Organization (FAO) estimates that the global demand for meat will increase by $73 \%$ between 2010 and 2050 (Gerber et al., 2013). The meat and dairy products market currently plays a very important role in the nutrition of society. Many consumers consider meat products to be a staple in their diets and an important source of nutrients (Verbeke et al., 2010). Slaughtered livestock provides a quarter of the protein and $15 \%$ of the energy of the global diet (Alexander et al., 2017). On the other hand, there 
is also growing awareness of the society about the negative impact on the environment associated with industrial farming, as well as the negative impact on human health associated with the consumption of meat, mainly red meat. Increasingly frequent global debates, a Greenpeace report, TV stations, and the statement of the International Agency for Research on Cancer on the classification of red meat as carcinogenic for humans emphasize the need to minimize the importance of meat in the diet (Apostolidis \& McLeay, 2016).

An alternative approach to reducing the consumption of traditional meat and meat products could involve replacing meat with non-meat products called meat analogues and with meat produced from stem cells. Meat analogues, or imitations of meat, are products composed of ingredients and using methods mimicking a specific type of meat as much as possible, including organoleptic characteristics such as: appearance, texture, color, smell, taste and nutritional properties, without using any meat products or their derivatives in their production. They are produced in various sizes and forms (disks, strips, sheets, etc.), varying from 6 to $20 \mathrm{~mm}$ and their fibrous and layered structure resembles that of meat. The bestknown meat analogues are products based on textured protein, including soy, pea or wheat, sea algae, tofu, tempeh, edible insects or 3D printed food. Research shows that meat substitutes have a lower environmental impact - they have lower greenhouse gas emissions, soil exploitation and energy consumption compared to the meat industry; they are also considered healthier for the human body. Despite these many advantages, the market for this type of replacement is small. In the UK and Europe in 2013 it accounted for only $3.6 \%$ of the value of the meat market. The low level of acceptance of meat substitutes by consumers may be caused by nutritional neophobia, perceiving these products as lower quality and higher prices compared to traction meat (Apostolidis \& McLeay, 2016; Bueschke et al., 2017; Florek, 2014; Jakubczyk, 2017).

Meat from cell cultures (stem cells) is produced by culturing stem cells in a medium that contains the necessary nutrients and a source of energy that allows the cells to reproduce and convert them into muscle cells. The main methods of cell meat production are either the biotechnological technique involving cell culture (the scaffold-based technique) or the tissue engineering technique (the self-organizing technique) (Edelman et al., 
2005). The world's first hamburger based on in vitro meat from cow stem cells was produced in 2013 . It cost $\$ 330,000$, currently the same product costs $\$ 50$ (Bhat, Kumar and Fayaz, 2015). In 2016, American start-up Memphis Meats created the first meatball made of bovine stem cells, and in 2017, it created artificial poultry meat, which according to a panel tasted exactly like conventional meat. The Maastricht team was able to bring the cost of producing an IVF meat burger down to $\$ 11.36$, which is a huge advance and has the potential to bring lab meat to market in the next few years. Cell culture meat can provide healthier, safer and disease-free meat for consumers, eliminating the environmental impact of conventionally produced meat. Even though this idea is only in the early stages of development, it may be a turning point for the food industry (Arshad et al., 2017; Bhat, Kumar \& Fayaz, 2015; Hocquette, 2016; Specht et al., 2018; Woll \& Böhm, 2018). The Singapore Food Agency (SFA) approved chicken meat obtained from stem cells for sale in 2020 (Ostaszewski, 2020).

Polish consumers are gradually adapting their market behavior to be similar to that which has developed in the societies of countries such as the United States and Japan. This process is conditioned by both universal factors and factors specific to Poland (related to traditions, experience and well-established patterns of behavior). Universal factors (i.e. demographic, economic, psychological, cultural) shape the attitudes and decisions of consumers in the market in a direction convergent with trends in many other countries. Some psychological factors, e.g. innovation, the degree of food neophobia, but also specific reactions under the influence of external stimuli affect the acceptance of food, especially food which is significantly different from its standard version well-known to the consumer. Increasingly often, scientists express the opinion that, compared to psychosocial features, sociodemographic features have a lesser impact on the acceptance of innovative food by consumers (Jeżewska-Zychowicz, 2014).

The key factor determining the development of new products is their quality and safety, which are closely related to the technical quality of the product, aimed at satisfying the food needs and expectations of consumers. The success of a new product on the market depends primarily on its acceptance. This criterion determines whether a new product is in fact an innovation and will be able to survive to the maturity stage, or whether it will be immediately rejected by the market. The aim of the study was to assess the perception of meat produced from stem cells in vitro by Polish consumers. 


\section{Methodology}

The study used a survey as the research method. The study was voluntary and was conducted based on an internet survey addressed to people aged 12 to $60+$. Convenience sampling of respondents was applied. The survey was conducted using a Computer-Assisted Web Interview (CAWI). The research sample consisted of 424 respondents with a diverse sociodemographic profile (Table 1). A total of 320 women and 104 men took

\section{Table 1. Structure of the sample}

\begin{tabular}{l|c}
\hline \multicolumn{1}{c|}{ Feature } & {$[\%]$} \\
\hline Sex & \\
woman & 75.5 \\
man & 24.5 \\
\hline Age & \\
12-18 years old & 13.2 \\
19-25 years old & 53.8 \\
26-30 years old & 16.5 \\
31-40 years old & 9.9 \\
41-50 years old & 2.4 \\
51-60 years old & 2.4 \\
60 plus & 1.9 \\
\hline Education & \\
basic & 9.9 \\
vocational & 2.8 \\
medium & 41.0 \\
higher & 46.2 \\
\hline Residence & \\
village & 22.6 \\
city up to 50,000 & 21.2 \\
city up to 100,000 & 11.3 \\
city up to 250,000 & 11.8 \\
city with over 250,000 & 33.3 \\
\hline Declaration of the consumption of meat & \\
and meat products in the daily diet & \\
I don't eat meat & \\
I eat meat & \\
\hline
\end{tabular}

part in the survey. The most numerous age group was 19-25, followed by the 26-30 and 12-18 age groups. In terms of education, the greatest 
number of people declared having higher and secondary education. There were fewer respondents with vocational and primary education. The largest number of respondents participating in the survey came from cities with more than 250,000 inhabitants, the next group were people from rural areas, then respondents from small towns up to 50,000 residents. The smallest number of respondents came from towns with up to 100,000 residents. $45.3 \%$ of the respondents declared that they do not consume meat and meat products in their daily diet. Analysis of variance (ANOVA) was performed to compare statistically significant differences of the results obtained. To verify the significance of differences between the mean values, Tukey's test $(\alpha=0.05)$ and the chi-square test $(\mathrm{p}<0.05)$ were applied using the Statistica 13.0 computer software.

\section{Results}

The results of the study indicate that over $1 / 3$ of the respondents knew and correctly identified the concept of meat produced from stem cells in vitro, with the majority of women, people with higher education and people declaring that they do not include meat in their daily diet (Table 2). The responses were dominated by the following statements: cell meat, meat raised with animal protein, artificial meat, synthetic meat, meat from the laboratory. A chi-square test $(\mathrm{p}<0.05)$ was conducted to examine the interdependence of the nominal variables. It was found that there were differences between the responses of men and women in terms of knowledge regarding IV meat $(p=0.915)$ and declaration of IV meat consumption $(p=0.958)$. In addition, analysis of variance was used to test whether the degree of education of the respondents affected the knowledge of IVM. The results indicate that there are three distinct groups. The first group includes respondents with primary and vocational education, the second group includes respondents with secondary education, and the third group includes respondents with higher education. The significance of the differences between the values of group arithmetical means was assessed based on the calculated value of the $F$ test (at the $\alpha=0.05$ level). Grouping of means into homogeneous groups was performed by Tukey's test. The results indicate the existence of three distinct groups. Group 1 
includes respondents with primary and vocational education, group 2, respondents with secondary education, and group 3, respondents with higher education.

\section{Table 2. Distribution of responses regarding the declaration of knowledge of the concept of meat produced from stem cells (in\%)}

\begin{tabular}{lc|c}
\hline Knowledge of the concept & \multicolumn{2}{c}{ Sex } \\
\hline & woman & man \\
\hline I know & 41.8 & 30.8 \\
I do not know & 58.2 & 69.2 \\
\hline
\end{tabular}

Education

\begin{tabular}{lc|c|c|c}
\hline & basic & vocational & medium & higher \\
\hline I know & 4.8 & 8.3 & 34.5 & 50.5 \\
I do not know & 95.2 & 91.7 & 65.5 & 49.5 \\
\hline
\end{tabular}

\begin{tabular}{lc|c}
\hline & \multicolumn{2}{c}{ Declaration of consuming meat in the daily diet } \\
\hline & I eat meat & I don't eat meat \\
\hline I know & 23.7 & 55.1 \\
I do not know & 76.3 & 44.9 \\
\hline
\end{tabular}

The literature contains the results of studies of consumer attitudes towards names describing meat in vitro, which are contradictory. This may result in the lack of consumer acceptance. The results reported by Fernandes, Fantinel, de Souza, and Révillion (2019) show that the use of such names as in vitro meat, artificial meat, synthetic meat, laboratory meat, cultured meat, cultured beef is favorable for consumer perception, as these names suggest that the product does not require slaughter and is an alternative to current farming systems. It is part of our responsibility to the environment. On the other hand, the results of studies conducted by Asioli, Bazzani, and Nayga (2018) indicate that the name in vitro meat was rejected by consumers due to its "artificiality" and lack of naturalness. This is also confirmed by the results of the studies by Chriki and Hocquette (2020) and Siegrist, Sütterlin, and Hartmann (2018). Consuming products alternative to meat finds its audience mainly among vegetarians and people avoiding meat due to their religion, concern for animal well-being and the 
environment, as well as people aware of the impact of meat consumption on health (Apostolidis \& McLeay, 2016).

The next question tested the respondents' knowledge of the current state of development of in vitro meat production. The subjects were asked if they believed that meat from cell cultures had ever been grown on a technical scale. This question was answered in the affirmative by $75.0 \%$ of respondents, including $83.3 \%$ of the total number of people who declared they do not eat meat and $69.8 \%$ of people who consumed meat. The potential interest in the development of in vitro meat production technology, interest in the product was declared by $63.9 \%$ of the respondents, with women dominating $(65.6 \%$ of all women participating in the study) and $59.6 \%$ of all men participating in the survey. Respondents in favor of the possibility of development had mainly higher and secondary education, respectively $70.4 \%$ and $60.3 \%$ of the total number of respondents with declared education.

The respondents were also asked about their willingness to try in vitro meat. The results are presented in Table 3. Among the respondents, 56.1\% would be willing to try meat produced from stem cells, including $55.3 \%$ of the women and $62.5 \%$ of the men taking part in the study. It is also interesting that as many as $65.1 \%$ of respondents who consume meat regularly declared their willingness to try meat in vitro, while $45.8 \%$ of respondents declared not consuming meat. In the case of the respondents' education, no differences resulting from their education were observed. The greatest willingness to try meat from cell cultures was expressed by residents of large cities with over 250,000 inhabitants. The potential interest in in vitro meat is most strongly differentiated in terms of the education level of the respondents and their place of residence. Considering the age criterion, the greatest willingness to try this type of product was expressed by the group aged 26-30 and 19-25. None of the respondents aged 60 plus participating in the survey showed willingness to try in vitro meat. The respondents were also asked a question regarding the declaration of an acceptable purchase price for meat produced from stem cells in vitro. 93.9\% of respondents declared that they are able to pay a higher price for in vitro meat compared to meat produced in conventional conditions, assuming its positive impact on the environment, health and comparable flavor, both among respondents declaring meat consumption 
Table 3. Distribution of responses regarding the declaration of willingness to try meat produced from stem cells in vitro (in \%)

\begin{tabular}{l|c}
\hline \multicolumn{1}{c|}{ Feature } & {$[\%]$} \\
\hline Sex & \\
woman & 55,3 \\
man & 62.5 \\
\hline Age & \\
12-18 years old & 57.1 \\
19-25 years old & 59.2 \\
26-30 years old & 60.0 \\
31-40 years old & 47.6 \\
41-50 years old & 40.0 \\
51-60 years old & 50.0 \\
60 plus & 0.0 \\
\hline Education & \\
basic & 54.8 \\
vocational & 58.3 \\
medium & 57.5 \\
higher & 56.1 \\
\hline Residence & \\
village & 64.6 \\
city up to 50,000 & 62.2 \\
city up to 100,000 & 45.8 \\
city up to 250,000 & 44.0 \\
a city with over 250,000 & 82.1 \\
\hline Declaration of the consumption of meat & \\
and meat products in the daily diet & 45.8 \\
I don't eat meat & \\
I eat meat & \\
\hline & \\
\hline & \\
\hline & \\
\hline & \\
\hline & \\
\hline
\end{tabular}

and no consumption of meat, respectively 90.5 and $96.9 \%$. There was a significant statistical difference between men and women $(\mathrm{p}=0.992)$, similarly between those who declared and those who did not declare consumption of meat and meat products in their daily diet $(p=0.918)$. The results of the analysis of variance allow us to find significant differences between the groups of respondents from the age ranges of 12-18 years; 19-25 years old; 26-30 years and 51-60 years (group A) and from the age ranges $31-40$ years; $41-50$ years (group B). No significant differences were 
found between the educational level of the respondents and their declarations (one group was distinguished). In terms of place of residence, significant differences were found between answers of respondents declaring a village and a town up to 50,000 inhabitants as their place of residence (group A) and answers of respondents living in towns up to 100,000 and up to 250,000 inhabitants (group B) and answers of respondents living in towns above 250,000 inhabitants (group C).

The results reported by Bryant, Szejda, Parekh, Desphande, and Tse (2019) indicate a potential market for in vitro meat. The willingness to try meat produced from stem cells was declared by $64.6 \%$ of respondents, $49.1 \%$ declared regular purchases of in vitro meat, and $48.5 \%$ would give up traditional meat for meat in vitro (Bryant et al., 2019). Less optimistic research results were obtained by the team of Hocquette (2015), which indicate that most better-educated respondents did not declare the regularity of purchasing in vitro meat; $1 / 3$ replied "I don't know." Interesting results were also reported by the Verbeke et al. (2015), indicating the necessity to educate consumers regarding meat produced from stem cells. In studies carried out in Belgium, Portugal and Great Britain, along with the increase in substantive information on in vitro meat, and the benefits of eating, consumers changed their attitudes from the original feelings of "reluctance" and "unnaturalness" towards the benefits that can be achieved by consuming this the food category.

The respondents were asked about the advantages and disadvantages of meat produced from stem cells. Among the advantages the respondents most often mentioned aspects related to environmental protection, e.g. reduction of waste generated during meat breeding and processing, improvement of the condition of the natural environment, reduction of the greenhouse effect (34 people), no need to kill animals, including reducing their suffering (20 people), elimination of breeding animals for slaughter (15 people), the possibility of obtaining lower in vitro meat production costs compared to conventional meat (12 people) and increasing the market offer (10 people). Among the disadvantages or concerns related to the production of in vitro meat, the respondents mentioned: lower quality, including possible negative impact on human health, the possibility of mutation and 
the emergence of new diseases (84 people), constant interference with the animal's organism, possible complications during biopsy, suffering, death of animals, threat to species (18 people), too much interference with nature, artificiality of the product (18 people), much higher price compared to conventional meat (10 people), genetic modifications (10 people) and adding enhancers and accelerators of the meat breeding process in vitro (6 people). It is also interesting that scientists still do not agree whether cultures produced from stem cells will have a positive effect on the environment. Doubts concern the reduction of greenhouse gases, water consumption, and energy consumption (Alexander et al., 2017; Lynch \& Pierrehumbert, 2019; MacLeod et al., 2013; Mattick et al., 2015; Tuomisto \& de Mattos, 2011, Zabielski \& Zarzyńska 2020).

The purposive selection of respondents used in the study (Internet users), means that the results and conclusions obtained do not provide a basis for generalization to the entire population. They make an interesting contribution to further research.

\section{Conclusions}

Meat produced from stem cells is presented as a humane, beneficial alternative to the progressive degradation of the environment compared to meat produced in traditional conditions. The results of the study showed a diverse range of interest among Polish consumers in meat produced from stem cells in vitro. Many respondents were not able to clearly define their preferences for this type of product. Young people showed the greatest positive interest in innovative in vitro meat. The greatest concerns expressed by Polish consumers were related to the lack of knowledge about this type of food, the lack of its inherent naturalness and potential negative health effects. The information obtained in this study may constitute a valuable information base for producers in the context of creating the quality and innovation of their product offer.

The development of new alternative meats is in line with the initiative of the European Commission Food 2020 to create sustainable food systems that lead to a climate-friendly and healthy Europe (an 
agenda for a climate-smart and sustainable food system for a healthy Europe). Directions and prospects for in vitro meat development will depend on consumer acceptance, the knowledge of consumers and factors such as: social, environmental, economic technologies, as well as legal regulations.

\section{Co-financed by the "Doskonała nauka"}

Program of the Minister of Science and Higher Education

\section{References}

1. Alexander, P., Brown, C., Arneth, A., Dias, C., Finnigan, J., Moran, D., \& Rounsevell, M. D. A. (2017). Could consumption of insects, cultured meat or imitation meat reduce global agricultural land use? Global Food Security, 15, 22-32.

2. Apostolidis, C., \& McLeay, F. (2016). Should we stop meating like this? Reducing meat consumption through substitution. Food Policy, 65, 74-89.

3. Arshad, M. S., Javed, M., Sohaib, M., Saeed, F., Imran, A., \& Amjad, Z. (2017). Tissue engineering approaches to develop cultured meat from cells: A mini review. Cogent Food \& Agriculture, 3(1), 1320814.

4. Asioli, D., Bazzani, C., \& Nayga, R. M. (2018). Consumers' valuation for lab produced meat: an investigation of naming effects. American Agricultural Economics Association (AAEA) Annual Meeting. Washington, DC.

5. Bhat, Z. F., Kumar, S., \& Fayaz, H., (2015). in vitro meat production: Challenges and benefits over conventional meat production. Journal of Integrative Agriculture, 14(2), 241-248.

6. Bryant, C., Szejda, K., Parekh, N., Desphande, V., \& Tse, B. (2019). A survey of consumer perceptions of plant-based and clean meat in the USA, India, and China. Frontiers in Sustainable Food Systems, 3, 11.

7. Bueschke, M., Kulczyński, A., Gramza-Michałowska, \& A., Kubiak, T. (2017). Alternatywne źródła białka w żywieniu człowieka [Alterantive sources of protein in human nutrition]. Zeszyty Naukowe Szkoty Gtównej Gospodarstwa Wiejskiego w Warszawie - Problemy Rolnictwa Światowego, 17(3), 49-59.

8. Chriki, S., \& Hocquette, J-F. (2020). The Myth of Cultured Meat: A Review. Frontiers in Nutrition, 7, 7 .

9. de Boer, J., Schösler, H., \& Aiking H. (2014). "Meatless days" or "less but better"? Exploring strategies to adapt Western meat consumption to health and sustainability challenges. Appetite, 76, 120-128.

10. Edelman, P. D., McFarland, D. M, Mironov, V. A., \& Matheny, J. G. (2005). in vitrocultured meat production. Tissue Engineering, 11(5-6), 659-662.

11. Fernandes, A. M., Fantinel, A. L, de Souza, A. R. L., \& Révillion, J. P. P. (2019). Trends in cultured meat: a bibliometric and sociometric analysis of publication. Brazilian Journal of Information Science, 13(3), 56-67.

12. Florek, A. (2014). Analogi mięsa - charakterystyka i perspektywy [Meat Analogues Characteristics and Prospects]. Przemyst Spożywczy, 68(1), 25-28. 
13. Gerber, P. J., Steinfeld, H., Henderson, B., Mottet, A., Opio, C., Dijkman, J., \& Falcucci, A. (2013). Tackling Climate Change through Livestock - A Global Assessment of Emissions and Mitigation Opportunities. Rome: Food and Agriculture Organization of the United Nations.

14. Hocquette, A, Lambert, C., Sinquin, C., Peterolff, L., Wagner, Z., Bonny, S. P. F., Lebert, A., \& Hocquette, J.-F. (2015). Educated consumers don't believe artificial meat is the solution to the problems with the meat industry. Journal of Integrative Agriculture, 14(2), 273-284.

15. Hocquette, J.-F. (2016). Is in vitro meat the solution for the future? Meat Science, 120, 167-176.

16. Jakubczyk, E. (2017). Drukowanie żywności w 3D. Nowe technologie [Printing food in 3D - New Technologies]. Przemyst Spożywczy, 71(1), 2-7.

17. Jeżewska-Zychowicz, M. (2014). Uwarunkowania akceptacji konsumenckiej innowacyjnych produktów żywnościowych [Conditions for Consumer Acceptance of Innovative Food Products]. ŻYWNOŚĆ. Nauka. Technologia. Jakość, 21(6), 5-17.

18. Lynch, J., \& Pierrehumbert, R. (2019). Climate impacts of cultured meat and beef cattle. Frontiers in Sustainable Food Systems, 3, 5.

19. MacLeod, M., Gerber, P., Mottet, A., Tempio, G., Falcucci, A., Opio, C., Vellinga, T., Henderson, B., \& Steinfeld, H. (2013). Greenhouse gas emissions from pig and chicken supply chains - A global life cycle assessment. Rome: Food and Agriculture Organization of the United Nations.

20. Mattick, C. S., Landis, A. E., Allenby, B. R., \& Genovese, N. J. (2015). Anticipatory life cycle analysis of in vitro biomass cultivation for cultured meat production in the United States. Environmental Science \& Technology, 49(19), 11941-11949.

21. Ostaszewski, J. (2020). Mięso hodowane komórkowo zatwierdzone w Singapurze [Cell Cultured Meat Approved in Singapore]. Food Fakty. https://foodfakty.pl/miesohodowane-komorkowo-zatwierdzone-w-singapurze (17.09.2021)

22. Siegrist, M., Sütterlin, B., \& Hartmann, C. (2018). Perceived naturalness and evoked disgust influence acceptance of cultured meat. Meat Science, 139, 213-219.

23. Specht, E. A., Welch, D. R, Rees Clayton, \& E. M., Lagally, C. D. (2018). Opportunities for applying biomedical production and manufacturing methods to the development of the clean meat industry. Biochemical Engineering Journal, 132, 161-168.

24. Tuomisto, H. L. \& de Mattos, M. J. T. (2011). Environmental impacts of cultured meat production. Environmental Science \& Technology, 45(14), 6117-6123.

25. Verbeke, W., Marcu, A., Rutsaert, P., Gaspar, R., Seibt, B., Fletcher, D., \& Barnett, J. (2015). "Would you eat cultured meat?": Consumers' reactions and attitude formation in Belgium, Portugal and the United Kingdom. Meat Science, 102, 49-58.

26. Verbeke, W., Pérez-Cueto, F. J., Barcellos, M. D. D., Krystalli, A., \& Grunert, K. G. (2010). European citizen and consumer attitudes and preferences regarding beef and pork. Meat Science, 84(2), 284-292.

27. Woll, S. \& Böhm, I. (2018). In-vitro meat: A solution for problems of meat production and meat consumption? Ernaehrungs Umschau International, 65(1), 12-21.

28. Zabielski, R. \& Zarzyńska, J. (2020). Wyzwania związane z produkcją sztucznego mięsa [Challenges related to the production of artificial meat]. Życie Weterynaryjne, 95(2), 74-80. 
Stanisław Popek - is a Professor of Social Sciences, employed at the College of Management Sciences and Quality, Institute of Quality and Product Management Sciences of the Cracow University of Economics. As an academic teacher and researcher, his scientific interests lie in the quality of food products, quality management, and consumer behavior in the food market.

Bogdan Pachołek — is an assistant professor at the University of Economics and Business in Poznań. Employed at the Product Marketing Department at the Marketing Institute. His research and teaching interests focus on consumer behavior, food innovation design and development, and product management. 